market; when there is a surplus, and buyers can afford to be particular, they may reject crops with $20 \%$ of such tubers, or even less. Such rejected crops then have to go for stock feed at $£_{3}$ or $£_{4} /$ ton-thereby fetching less than a third of the ware price.

After even this brief review of the losses caused by the three principal diseases of potatoes in this country, one cannot escape the reflection that lack of rain is more often responsible for shortages of potatoes in these days than all the potato diseases put together. When the soil moisture is deficient the potential yield is low, common scab is worst, the potato spraying that is done against blight is almost entirely wasted and, incidentally, the aphids that spread the principal potato virus diseases are most abundant.

\title{
REFERENCES
}

Bawden, F. C. (1959). Proc. R. Soc. B, 131, 57.

Beaumont, A. (1959). In Diseases of Farm Crops. London: Collingridge.

Broadbent, L., Burt, P. E. \& Nix, J. S. (1957). N.A.A.S. Quart. Rev. 38, 444.

Cox, A. E. \& Large, E. C. (1960). Agric. Indbk no. I74. Washington: United States Department of Agriculture.

Large, E. C. (1958). Plant Path. 7, 39.

Large, E. C. (1959). Agriculture, 65, 603.

Large, E. C., Blenkinsop, A. \& Le Riche, H. H. (1946). Agriculture, 53, 2 I r.

Large, E. C. \& Honey, J. K. (r955). Plant Path. 4, I.

McKay, R. (1955). Potato Diseases. Dublin: At the Sign of the Three Candles.

Moore, W. C. (1959). British Parasitic Fungi. Cambridge: University Press.

Whitehead, T., McIntosh, T. P. \& Findlay, W. M. (1953). The Potato in Health and Disease. Edinburgh: Oliver \& Boyd.

\section{Food losses through animal disease}

\section{By F. B. LEECH, Rothamsted Experimental Station, Harpenden, Herts}

The principal sources of food derived from the farm stock of the United Kingdom (Table I) are milk and cattle meat. Although sheep are three times as numerous as pigs, they produce only one-third as much food. Poultry, because of their egg production, are about equal in importance to pigs.

Table x. Approximate amount of food (thousands of tons) produced in a year by the four main species of farm stock in the United Kingdom

$\begin{array}{lrcccr}\text { Species } & \text { Meat } & \text { Offal } & \text { Milk } & \text { Eggs } & \text { Total } \\ \text { Cattle } & 820 & 70 & 2570^{*} & - & 3460 \\ \text { Sheep } & 200 & \text { I } & - & - & 2 \text { 7 } \\ \text { Pigs } & 590 & 50 & - & - & 640^{\circ} \\ \text { Poultry } & 210 & - & - & 560 & 77^{\circ}\end{array}$

Animal diseases affect this food supply by causing mortality among the farm stock, by making the food unpalatable (tough or tainted) or unsafe for human consumption, by reducing the efficiency of food conversion and also by reducing the per capita output, for example by causing loss of appetite. They also cause indirect loss through the cost of rearing replacements for the casualties. 
Statistics relevant to the estimation of food losses can be found in reports on farm surveys of animal morbidity and mortality, in returns from slaughter-houses showing the quantities of diseased meat condemned as unfit for human consumption and in returns of the compulsory slaughter of animals affected by certain notifiable diseases. Experimental results can show the loss occurring in controlled conditions, but considerable caution is required when extrapolating from experimental to field conditions.

I have drawn the information contained in this paper from three main sources, the survey in Northern Ireland (Gracey, 1960), a survey of disease of dairy cows in Great Britain (Leech, Davis, Macrae \& Withers, I960) and a survey of losses of breeding ewes in Great Britain. These were all on a very much larger scale than any previous work, and random samples of all the relevant populations of farms were used. They should therefore be much more representative than small surveys of selected farms.

Information about returns from slaughter-houses during the last quarter of 1959 and about the compulsory slaughter of animals affected by notifiable diseases during the Io years I950-1959 was supplied by the Ministry of Agriculture, Fisheries and Food.

\section{Cattle}

Losses of calves. Recent surveys agree (Gracey, I960; Withers, 1952) in ascribing $30 \%$ of the calf mortality to Escherichia coli infections. This is easily the most important single disease. The total mortality of calves in the first 6 months of life is given by Gracey as $2 \cdot 8 \%$ in Northern Ireland. Withers found $7.4 \%$ mortality on a set of farms in Great Britain selected in part because of their heavy losses.

Losses of young and store stock. From 6 months to 3 years of age the total mortality was $1 \cdot 7 \%$, of which one-fifth was ascribed to parasitic bronchitis, and one-eighth to blackquarter. This information comes from Northern Ireland where Johne's disease is not a serious problem.

Losses of cows. A recent survey (Leech et al. 1960) of a random sample of dairy herds of Great Britain revealed $2 \%$ mortality, including both animals dying on the farm and animals slaughtered at the knackery. Of this mortality, $22 \%$ was ascribed to Johne's disease, $16 \%$ to milk fever, I I $\%$ to mastitis, I $1 \%$ to dystokia and $7 \%$ to grass tetany.

Milk losses. In addition to the loss caused by mortality, by diseases causing loss of appetite and by diseases reducing the efficiency of food conversion, milk yield may also be reduced by diseases that directly attack the udder tissue and by abortion. The effect of abortion has recently been estimated by L. K. O'Connor ( 1960 , personal communication) to be $38.2 \mathrm{lb}$ for each day by which the gestation period is shortened. The majority of abortions occur at 6-7 months and are, therefore, associated with a loss of 200-300 gal of milk. The estimated national average of $2 \%$ abortions (Leech et al. 1960) thus reduces the national milk supply by about $0.5 \%$, though probably at most a quarter of this reduction could be saved by the control of disease. The saving should be of the order of $3-6$ million gal/annum, depending on the incidence of abortion during the year. 
Numerous attempts have been made to estimate the effect of mastitis on milk yield, but few of these are beyond criticism. McLeod \& Wilson (r95 I) estimated that untreated mastitis caused a loss of $24 \%$ of the total lactation yield, and O'Donovan, Dodd \& Neave (1960) estimated a $10 \%$ loss in cows treated with antibiotics, both groups of workers using similar methods of estimation which contained the same logical error. It is very probable that the real losses were less. An investigation of the yields of pairs of identical twins showed that when one quarter was affected, the reduction in the yield of the affected quarter tended to be very largely compensated for by increased yield in other quarters, the affected cows in five pairs yielding, on the average, $99.6 \%$ of the yield of their identical twins (D. H. McLeod, 1958, personal communication). There is clearly a substantial loss when three or four quarters are severely affected and, of course, when the cow dies, but this situation is relatively infrequent. With the present widespread use of antibiotics it seems likely that the average loss per infected cow may be nearer 5\% than $10 \%$.

Losses at abattoirs. The main causes of carcass condemnation were joint-ill of calves (an $E$. coli infection) and tuberculosis of adult cattle. The latter disease is rapidly being eliminated. Twenty-five per cent of cattle livers were condemned because of liver-fluke infestation.

Foot-and-mouth disease. The numbers of cattle slaughtered on farms affected by foot-and-mouth disease has varied greatly from year to year. The average loss over the last Io years has been similar in extent to the mortality attributed to grass tetany in $1957-8$.

\section{Pigs}

Surveys in Northern Ireland (Gracey, I960) and in England and Wales (Veterinary Investigation Service, 1959) both showed that $20 \%$ of piglets born alive failed to survive for 8 weeks. The great majority of these deaths were ascribed to factors in which no overt disease was involved-principally accidental crushing by the sow. In Northern Ireland, mortality after weaning was about $3 \%$, one-third of it being caused by bowel oedema of fattening pigs. Compared with these losses, the numbers compulsorily slaughtered because of swine fever have in the last ro years been trivial. Avian tuberculosis affected about $\mathrm{I} \cdot 2 \%$ of carcasses, most of which required partial condemnation. Ascaris infection caused the condemnation of $4 \frac{1}{2} \%$ of livers.

\section{Sheep}

A recent survey in England and Wales (Leech, I 960, unpublished) showed that $5 \%$ of breeding ewes died in October 1958 - March 1959 , and a further $2 \%$ died between April and September I959. No diagnosis of the causes of loss was attempted in this survey.

Gracey (1960) recorded 5.8\% mortality per annum for $1954-5$ in Northern Ireland, of which one-fifth were ascribed to pregnancy toxaemia and one-eighth to liver-fluke disease. In lambs, he found ir \% mortality, mainly ascribed to environmental 
factors. Pulpy-kidney disease caused $16 \%$ of this mortality, equivalent to $1 \cdot 7 \%$ of live births. In yearlings and rams, braxy was said to cause a quarter of the total $(6 \cdot 3 \%)$ deaths.

Gastro-intestinal parasites were not on the average a major cause of mortality, but there is good evidence to show that they reduce appetite and the efficiency of food conversion.

At slaughter-houses, very few carcasses were condemned because of disease, but parasitic diseases (liver fluke, hydatid cysts and parasitic pneumonia) affected 5.6\% of the offal, accounting for $77 \%$ of the condemnations. Although livers affected with hydatid cysts are condemned for human consumption, they are released for pet feeding and are in fact fed to dogs. Dogs are the intermediate host of the parasite, and as the dogs and not the sheep livers infect human beings, these arrangements seem specially designed to perpetuate the disease.

\section{Poultry}

As yet, surveys of poultry losses have been restricted to one or a few flocks and may not represent the national picture of losses at all closely. Coles (I955) found that $22 \%$ of pullet chicks hatched had died before they were 18 months old, nearly half this mortality being caused by the 'avian-leucosis complex' affecting birds between I I and 45 weeks old. Jordan (1956), from a survey in mid-Wales found that in the first 2 weeks mortality was mainly caused by management factors. Between 2 weeks and 6 months of age, bacterial and parasitic infections (mainly bacillary white diarrhoea and coccidiosis) were the principal causes of mortality. Between 6 months and 12 months of age the principal losses were caused by tumours, this term including the avian-leucosis complex. After 12 months tumours and reproductive diseases caused about equal losses, the reproductive disease being mainly egg peritonitis.

\section{Conclusions}

I have confined my attention to national averages where these are available, thus obscuring a considerable variation from farm to farm. A few farms may suffer heavy losses from a disease that is of minor national importance; these outbreaks tend to get publicity, but, putting them into perspective, it seems to me that the disease position in this country is reasonably good. The most important point is to keep out of the country the diseases we have got rid of and to avoid introducing exotic ones. The consequences of the reintroduction of fowl pest during the war underline this point.

The losses of young animals seem to me susceptible of reduction through extension work, for methods of reducing many of these losses are known, though the knowledge is perhaps not sufficiently available to farmers who could benefit from it.

In growing ruminants, the control of parasitic diseases involves at present some degree of reorganization of pasture management and is therefore only partly satisfactory. An ideal method of control would permit a farmer to keep cattle or sheep when and where he wanted them. 
Among unsolved problems of some importance are the control of Johne's disease, of tumours ('avian-leucosis complex') of fowls and of bowel oedema of pigs.

\section{REFERENCES}

Coles, R. (1955). Brit. vet. $\mathcal{F}$. Irr, 235.

Gracey, J. F. (1960). Survey of Livestock Diseases in Northern Ireland. Belfast: H,M. Stationery Office. Jordan, F. T. W. (1956). F. comp. Path. 66, I97.

Leech, F. B., Davis, M. E., Macrae, W. D. \& Withers, F. W. (1960). Disease, Wastage and Husbandry in British Dairy Herds. London: H. M. Stationery Office.

McLeod, D. H. \& Wilson, S. M. (1951). F. Dairy Res. 18, 235.

O'Donovan, J., Dodd, F. H. \& Neave, F. K. (r960). F. Dairy Res. 27, 115.

Withers, F. W. (1952). Brit. vet. $\not{f} .108,315$.

Veterinary Investigation Service (1959). Vet. Rec, 7r, 777. 